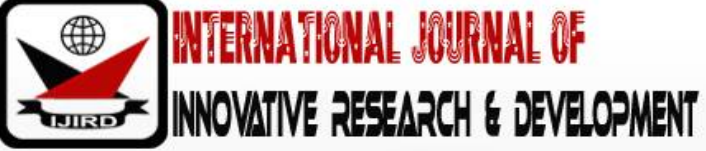

ISSN 2278 - 0211 (Online)

\section{Principal's Support of Peer Education and Prevalence of Drug and Substance Abuse in Public Secondary Schools in Busia County, Kenya}

\begin{tabular}{c}
\hline Judith Mary Aguttu \\
Ph.D. Candidate, Department of Educational, Administration and Planning, \\
University of Nairobi, Kenya \\
Jeremiah Kalai \\
Associate Professor, Department of Educational, Administration and Planning, \\
University of Nairobi, Kenya \\
Lewis Ngesu \\
Associate Dean, Department of Educational Foundations, University of Nairobi, Kenya
\end{tabular}

\begin{abstract}
:
The study sought to determine whether significant differences existed between levels on prevalence of drug and substance abuse in schools where principals supported peer education versus those who did not support peer education. The study utilized descriptive survey design and the target population of students was 30,745. Out of 30745, 420 students formed sample size for the study from 35 schools, 35 principals, five education officers for focus group discussion and 35 guidance and counseling teachers totaling to 495 respondents. Instruments used were questionnaires for students and guidance and counseling teachers, interview guide for principals and focused group discussion. The computer program on statistical package for social Sciences (SPSS) was used in the analysis. Levene's t -test for equality of variances and means was used for independent and dependent samples to get the significance on prevalence of drug and substance abuse. The study established that schools which led peer education have a significant difference on the prevalence of drug and substance abuse hence have higher education, the study established that there were various ways in which peers participated to address the prevalence on drug and substance abuse. These ways are through use of peers to address drug and substance abuse, through use of clubs, through use of societies to address drug and substance abuse, through use of skits, use of plays, use of music and finally through use of drama to address drug and substance abuse. The study also identified the drug and substance abuse by the students in public secondary schools in Busia County. These drug and substance included the following: alcohol, tobacco, cigarettes, miraa, cocaine, bhang, kubber, mandrax and hashish. The study concluded that peer education positively influenced students' behavior in the sense that they reduced drug and substance abuse among the students. The study recommends embracing of peer education in all secondary schools where they were not yet embraced as a preemptive measure. The study should be carried out in private secondary schools and primary schools in other parts of the Republic where drugs are a menace. The study also recommended that the ways in which peers participated to address the prevalence on drug and substance abuse in public secondary schools in Busia County, Kenya should be enhanced.
\end{abstract}

Keywords: Peer Education, activities for peer education, drug and substance abuse

\section{Introduction}

Drug and substance abuse among the youth is a major challenge facing the education sector globally, it creates a social-economic hardship, breeding misery which increases crime, violence and adrain in all affected strata of the society. According to a survey conducted by the United Nations Office on Drugs and Crime (UNODC, 2010), the war against drug abuse is far from over and drug barons are so powerful and ruthless that they are able to hold at ransom any one standing in the way of their evil trade irrespective of his / her position of authority. Countries like Peru, Bolivia and Colombia have large plantations of cocaine, while opium poppy a flower like plant from which heroin is produced grows illegally in Pakistan and Afghanistan (Golden Crescent) and around Cambodia, Thailand and Laws (Golden triangle) United Nations Office on Drugs and Crime (UNODC, 2013).

Balding (2011) in a national survey conducted in England revealed that up to 53 percent of 14 to 15 -year olds are more likely to have been offered and taken drugs. The opium war of 1839 between Britain and China was triggered by drug trade. In 1992, the UN Secretary General Bouturos Boutros Ghali lamented the escalation in drug abuse among the youth and emphasized that the war against Drug and Substance Abuse (DSA) should be fought by all nations (United 
Nations, 2000) the Secretary General. He called on all UN member states to enact drug trafficking laws that would significantly reduce the global illicit drug supply and demand (United Nations Office on Drugs and Crime, 2013).

In Africa, the drug problem is part of the larger social problem that affects Sub-Saharan African (SSA) Nations which have been transformed from transit points in an international drug network to consumer countries (Affinity, 2008). Three decades ago, in a network on alcoholism and drug addiction in Africa held in Nairobi Kenya, poverty, moral decadence and lack of good will among the leaders were found to major hindrances to fight against drug related crime in many African countries (Olatuwara \& Odejide, 2006). However, the situation is not different today as indicated by Odejide (2006) who further blamed inability to decisively deal with drug abuse in many Africa countries and schools on rampant corruption and involvement of organized cartels in the drug trade.

The issue of drug abuse is therefore not new in our Kenyan public secondary schools but has only escalated. According to a survey done by the big issue team, there is a general consensus that the problem of drug abuse and trafficking in schools is on the increase (East African Standard, January 19, 2004). Another research done by the National Agency for the Campaign Against Drug Abuse (NACADA) shows that up to 92 percent of children aged between 16 and 26 are reported to have experimented with drugs, more than half of these stop using the drugs after sometime but 25 percent continue abusing the substance (Maithya, 2009).

The role of the principal to develop strategies through use of peer education. This can be through quarterly meetings, peers and alumni talks to their fellow age mates to change the behaviour of drug abuse in schools (Okumbe, 1999; and Obiero, 2006). The general objective for teaching the DSA topic is to create awareness and deter the use of drugs by students (KIE, 2002 and 2008). In 2002, at the Olympic Aid Round Table Forum in Salt Lake City, the then UN Secretary General, Koffi Annan stated that "sport can play a role in improving the lives of individuals and the whole community, He encouraged stakeholders to involve the youth in sports from an early age to enhance responsibility and professionalism.

Peer education has been instrumental in the fight against DSA according to (Chand, 2008 and Mungai, 2007). Mungai (2007) further noted that individual counseling, group counseling, peer counseling, mentoring and role modelling are used to help students overcome drug abuse. Through peer education, students are taught the dangers of DSA and how to overcome peer pressure to smoke or drink (Botvin, 2000). Republic of Kenya Principals and teachers are involved in prevention, control and mitigation of DSA through formal and non-formal peer education. The study also emphasizes role modelling where students learn responsible behaviour from their teachers. Furthermore, the teachers code of ethics and conduct prohibits smoking and drinking in the presence of students (Republic of Kenya, 2005).

Curbing Drug and substance abuse through peer education programming is based on the premise that younger students will relate to and benefit from the diverse experiences of slightly older students. Darcis (2004) they are more likely to be engaged by and receptive to the information and learning opportunities presented by those who are in similar situations to themselves. (Hyman \& Perone, 1998). Parent Action on Drugs (PAD) has developed and delivered peer-led substance misuse prevention programme for over two decades. (Ehlenberger, 2005; Johnson, 2000). The programmes are developed in partnership with key stakeholders including the youth themselves and have been shown to have a significant impact on both the peer leaders and the younger students. Peer education is based on the reality that many people make changes no only based on the opinions and actions of their close trusted peers (Ngesu, Ndiku \& Masese, 2008).

\section{Statement of the Problem}

Drug and Substance Abuse is rampant among students in secondary schools in Kenya and efforts by principals to mitigate the problem have yielded insignificant results. This trend is fueled by proximity to drug peddlers, high levels of poverty, ease of availability and slum life which make many students vulnerable to the allure of drugs (NACADA, 2006; and Republic of Kenya, 2008).

As a policy strategy to curb DSA, the Ministry of Education established DSA departments in every district, infused DSA in the school curriculum (KIE, 2002; 2008) and established peer education in schools (Republic of Kenya, 2008). However, with these policies in place among others, the problem continues to escalate with reported cases of students using drugs and causing irregular damages to school property, fellow students and the community at large. This was blamed by the Ministry of Education Science and Technology. Principals also use, drama, sports, music, peers, clubs, societies, plays and fellow students and resource persons to further create DSA Awareness (Muraguri, 2004); Matsiguru 2006; Mungai, 2007), studies by Ng’ang'a (2003), Kwamanga (2003), Muraguri (2004), Matsiguru (2006), King'endo (2007), Mungai (2007), Munyoki (2008), Maithya (2009) and Kimori (2010) explored other aspects of DSA but more explored principals' strategies used to curb drug and substance abuse in public secondary schools in Busia county, Kenya.

The drug and substance abused in schools are alcohol, tobacco, miraa, cocaine, bhang, kubber, heroine, mandrax and hashish. The principal's use quarterly meetings, peers and alumni talks to their fellow agemates to change the behaviour of drug abuse in schools. Many studies have been carried out on eradication of drug and substance abuse for instance the National Strategy on Prevention, Control and Mitigation of Drug and Substance Abuse, Drama, sports, music have also been used to stop drug abuse but none of the above have come up with the solution to curb drug and substance abuse in Busia County in public secondary schools. It is because of the persistence of drug and substance abuse still in public secondary schools in Busia County which promoted the researcher to investigate the effectiveness of using peer education on the prevalence of drug and substance abuse. The school's which carryout peer education have higher levels on prevalence of drug and substance abuse compared to those schools which do not have peer education. 


\section{Purpose of the Study}

The purpose of the study was to investigate the use of peer education on the prevalence of drug and substance abuse.

\section{Objectives of the Study}

The study attempted to meet the following objectives

- To examine influence of principals' support of peer education on the prevalence of drug and substance abuse in public secondary schools in Busia County, Kenya.

- To establish the ways in which peers participate to address the prevalence on drug and substance abuse in public secondary schools in Busia County Kenya.

- To identify the drugs and substance abused by the students in public secondary schools in Busia County, Kenya.

\section{Theoretical Framework}

The study is based on the social resistance skills theory as proposed by Gilbert Botvin in 2010.The social resistance skills theory argues that social and psychological factors are central in promoting the onset of cigarette smoking and latter, drug and alcohol abuse. The social resistance theory holds that drug abuse result from pro-drug social influences from peers, persuasive advertising appeals and media portrayals encouraging drug use, along with exposure to drug-using role models. The causes of drug abuse cited in this study, centre on some of the above psychosocial factors. Based on this theory, principals need to adopt, secondary indication in the environment (including not only physical aspect of the environment but also the addicts life style) is associated with the primary stimuli of the addict's drug experience resistance skills programmes as a whole have generally been successful in the U.K. A comprehensive review of resistance skills studies published from 1980 to 1990 reported that the majority of prevention studies (63 percent) had positive effects on drug use behavior, with or negative effects on behavior (11 percent) (Botvin, 2000).

The most popular school-based drug education programme based on the social influence theory is Drug Abuse Resistance Education or project (DARE). The limitations of the social resistance skills approach are that it assumes that young people do not want to use drugs but lack the skills or confidence to refuse. For some youth, however, using drugs may not be a matter of yielding to peer-pressure but may have instrumental value, it may for example help them deal with anxiety, low self-esteem or lack of comfort in social situations. For some, use of drugs especially alcohol makes them feel grown-ups. The theory also assumes that if youths are not exposed to drugs, drug using role models and pro-drug social influences, then they are unlikely to become drug abusers.

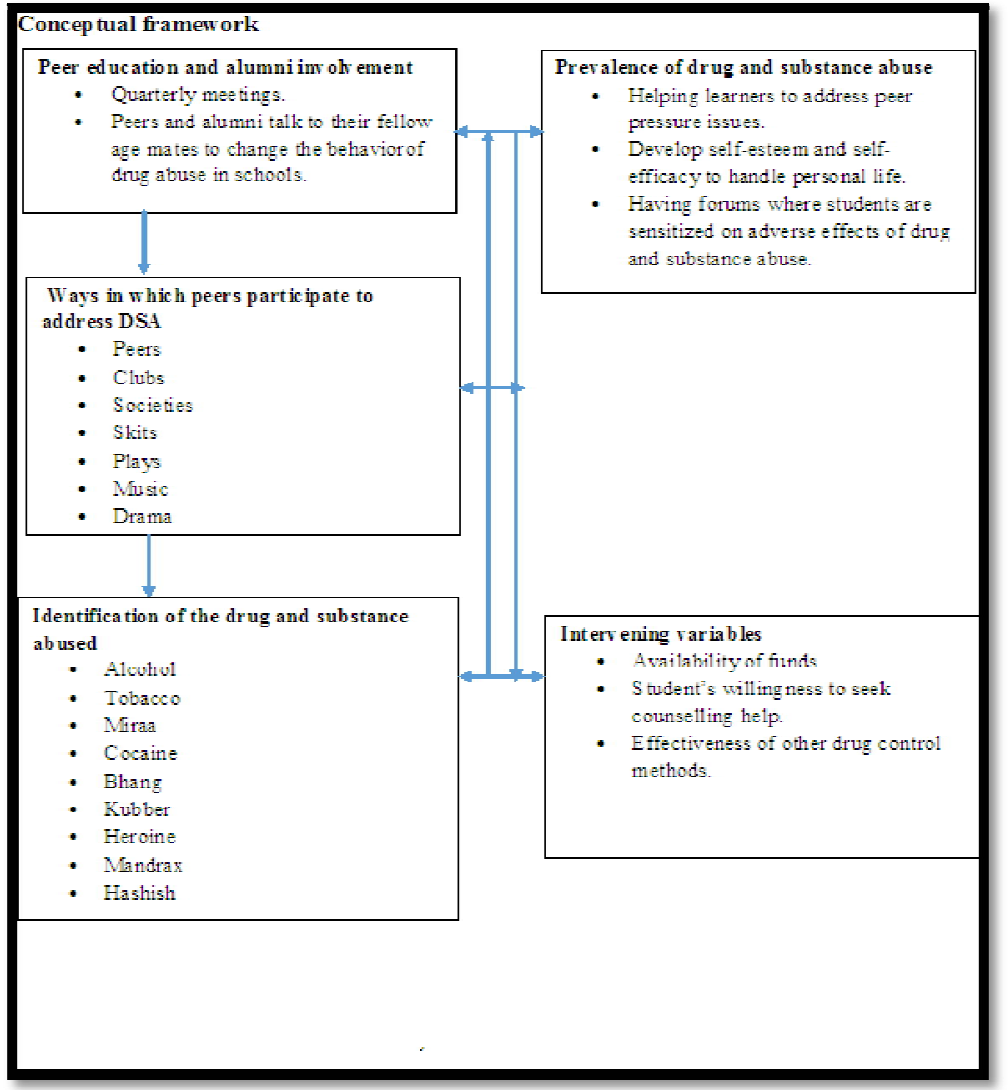

Figure 1: Mentoring Programmes and Drug and Substance Abuse among Students

The conceptual framework is a concise description of the phenomenon under study accompanied by a graphic depiction of the major variables of the study (Mugenda, 2008). It is the perspective or the set of lenses through which the researcher views the problem. It conceptualizes the interrelationships between the two study variables, in this case, 
principals' practices used curb DSA (independent variable) and prevalence of drug and substance abuse in schools (dependent variable) as shown in figure 1.

The conceptual framework shows mentoring programmes in curbing DSA among students. In this study, the level of DSA is conceptualize as an outcome of principals' administrative strategies. The principals' characteristics and the school category influence the strategies used to create awareness and shape the students' behaviours. School rules play to deter abuse of drugs and substance. NACADA involved in initiating intervention programmes enacting and enforcing drug trafficking laws, teaching moral values to students and reporting cases of traffickers and abusers within the context of the DSA mitigation process so that the use of Drug and Substance Abuse in schools is reduced.

\section{Research Design}

Descriptive survey design was used to obtain information from various departments. Orodho and Kombo (2003) described descriptive survey as a method of collecting information by interviewing or administering a questionnaire to a sample of individuals. It can be used when collecting information about peoples' attitudes, opinions, habits or any of the variety of education or social issues (Orodho \& Kombo, 2003).

\section{Target Population}

Mugenda and Mugenda (2003) defined a sampling frame as a list, directing on index of cases selected. According to list obtained from the County Director of Education office (2013), Busia County had 68 public secondary schools, 19 boys, 20 girls and 29 mixed schools. The population for the students was 30,745. Out of 30745, 420 students were chosen for the study. All the 68 principals, 68 heads of guidance and counselling and all the 420 students formed the target population of the study.

\subsection{Sample Size and Sampling Procedures}

Best and Kahn (2010) define a sample as a small proportion selected for observation and analysis. Fifty percent of the schools, principals, heads of guidance and counselling department and 50 percent of the students were used as recommended by Mugenda, (2008). Stratified sampling was used to classify schools into; girls only, boys only and mixed schools, mainly because single gender schools are fine with different experiences or the problem of drug abuse hence adopt different strategies to curb the problem compared to mixed schools as observed by (Imbosa, 2009). The summary of the target population and sample size of the school type is shown in table 1.

\begin{tabular}{|c|c|c|c|c|c|c|c|c|}
\hline $\begin{array}{c}\text { School } \\
\text { Type }\end{array}$ & $\begin{array}{c}\text { Target } \\
\text { Pop }\end{array}$ & $\begin{array}{c}\text { Sample } \\
\text { Size }\end{array}$ & $\begin{array}{c}\text { Head } \\
\text { Teacher }\end{array}$ & $\begin{array}{c}\text { HOD } \\
\text { G\&C }\end{array}$ & Form 1 & Form 2 & Form 3 & Form 4 \\
\hline Boys & 19 & 10 & 10 & 10 & 30 & 30 & 30 & 30 \\
\hline Girls & 20 & 10 & 10 & 10 & 30 & 30 & 30 & 30 \\
\hline Mixed & 29 & 15 & 15 & 15 & 45 & 45 & 45 & 45 \\
\hline Total & 68 & 35 & 35 & 35 & 105 & 105 & 105 & 105 \\
\hline
\end{tabular}

Table 1: Sample Size per School Type

l,

$n=p \% \times q \% \times\left(\begin{array}{l}z \\ e\end{array} \%\right) 2$ i.e. $7 \% 72$, where $\mathrm{n}$ is the minimum sample size required if the target population is greater than $1000 . \mathrm{P} \%$ is the proportion in the target population estimated to have the characteristic (assume $5 \%$ if unknown). $\mathrm{Q} \%$ the proportion estimated not to have the characteristic (l-p) $\mathrm{z}$ is the standard normal deviation at the required confidence level $\mathrm{e} \%$ is the level of statistical significance. Substituted as;

$50 \times 50 \times[1.96 / 5] 2=2500 \times(0.392) 2-2500 \times 0.154=385$

385 students

Selection of students; to calculate the sample of students, the formula provided by Sounders, Lewis and Thornwill (2007); and Mugenda (2008) was used. The formula was preferred because it gave a fair presentation of students per class and gender.

Selection of principals: after selecting 50 percent of schools in the county, all the principals of the selected schools were used in the study using stratified proportionate sampling; hence a total of 35 principals, selection of H.O.D Guidance and Counseling; All the heads of guidance and counseling departments in the 35 selected schools were included in the study by stratified proportionate sampling because they are responsible for guiding students and counseling those with Drug and Substance Abuse problems in schools.

The table shows the study population and the sample of schools, principals, H.O.D's guidance and counseling and students as per their class. Selection of schools; simple random sampling was used to select 50 percent of each type; giving a total of 10 boys' schools, 10 girls' school and 15 mixed school. There were two national schools which were purposively included in the study, that is, one boys' school and one girls' school. The study noted there is no mixed national school in Busia County.

\subsection{Instrument for Data Collection}

The researcher used questionnaire for students, questionnaire for guidance and counseling, interview guide for principals and group discussion with officials from education office. The questionnaire was preferred overall the others 
because it normally takes less time to construct and was cheaper to administer according to Mugenda and Mugenda (2003). It also gives no room for irrelevant information as is the case with other instruments like interviews (Mugenda \& Mugenda, 2003). The questionnaires were divided into objectives. There was a questionnaire for students, questionnaire for guidance and counseling teachers, there was interview guide for the principals and focus group discussions for education officers.

\subsection{Validity of Research Instrument}

Five questionnaires were distributed to five research experts at University of Nairobi. The responses received in the questionnaires were analyzed in terms of content validity, which addresses the extent to which the questionnaire provides adequate coverage of the topic provided under study. The interview guide was conducted for the principals and was analyzed. This ensured that the data obtained from questionnaire was meaningful and accurate. The group discussion was also analyzed and presented in the way it is supposed to be.

The researcher incorporated in the instrument's inputs from experienced researchers and graduate research supervision, the discipline of Educational administration, through their advice, more items were modified or omitted completely to improve the validity of instruments. However, the overall aim was to improve instrument items and gather the intended data.

\subsection{Reliability of Research Instrument}

Reliability refers to the extent to which the measure is without bias or results is consistent overtime, was done using the test -retest reliability method. This was used because of ease of accessibility and availability of the participants. The five questionnaires were re-administered to the experts after two weeks. A test -retest method was used to determine reliability of the interviewer schedule. This involved administering the instruments first group with similar characteristics to survey or research settings then the instrument items were improved depending on extent to which the items were suitable to gather the required information when instruments were administered in the main study. This method ensured that the instrument gathered relatively the same information obtained in the first test when administered in the main study. This is due to the fact that ambiguous difficulty and unclear items were either simplified or discarded altogether or new items added to instruments depending on the outcome of the first test.

\subsection{Data Collection Procedures}

The researcher started data collection after seeking and obtaining a research permit from National Commission of Science, Technology and Innovation (NACOSTI) to conduct research from the various public secondary schools in Busia County. The researcher then contacted the County Director of Education to be allowed to carry out the research in the county. The researcher also contacted the County Commissioner to be allowed to carry out research in the county. The sampled schools were visited and the principals informed about the study were explained to the respondents. The questionnaires were self, administered to students, guidance and counselling teachers who were the respondents. Thereafter, the interview schedule was used on principals after explaining to them the purpose of the study. Also, the focused group discussion was conducted with County Education Officers adequately. There were five County Education officials who participated in the study. These were County Director of Education, (Teachers Management), County Director of Education, County Quality Assurance, County Human Resource and Sub-County Director of Education.

\subsection{Data Analysis Techniques}

The data collected was organized, tabulated and analyzed using descriptive and inferential statistics, frequencies and percentages were used and presentation was done using graphs as summary. The gender difference on perception of drug abuse was analyzed so as to ascertain the facts in both males and females on drug and substance abuse if they all abuse. This is so because also female school types boarding was picked up for the study. Perception of the students on drugs and substance use and its effects on behavior towards drugs was done. The computer programme on statistical package for social sciences (SPSS) was used to assist in data analysis. Analysis of data was important in explaining the variables of the study. The data from the interview scheduled for the principals was analyzed using a descriptive statistic.

Comparison of schools where principals conduct mentoring programmes versus those which do not conduct in relation to prevalence of drug and substance abuse was carried out. Percentages and frequencies of prevalence of drug and substance abuse was carried out on this mentoring programmes. T.test was done to determine whether significant differences existed in drug and substance abuse among students where principals conducted student mentoring programmes and where they did not.

\section{Findings and Discussion on Principals' Support of Peer Education and Prevalence of Drug and Substance Abuse}

Peer education was carried out in 29 schools at 83 percent. It was only 6 schools which did not have peer education and this was at 17 percent.

Forms of peer education to address drug and substance abuse 


\begin{tabular}{|c|c|c|c|}
\hline $\begin{array}{c}\text { Statement } \\
\end{array}$ & Response & Frequency & Percent \\
\hline $\begin{array}{c}\text { Does your school use peer to address drug and } \\
\text { substance abuse? }\end{array}$ & $\begin{array}{c}\text { Yes } \\
\text { No } \\
\text { total }\end{array}$ & $\begin{array}{l}261 \\
140 \\
401\end{array}$ & $\begin{array}{l}65.1 \\
34.9 \\
100\end{array}$ \\
\hline $\begin{array}{l}\text { Does your school use club to address drug and substance } \\
\text { abuse? }\end{array}$ & $\begin{array}{l}\text { Yes } \\
\text { No } \\
\text { total }\end{array}$ & $\begin{array}{l}299 \\
102 \\
401\end{array}$ & $\begin{array}{c}79.6 \\
25.4 \\
100.0\end{array}$ \\
\hline $\begin{array}{c}\text { Does your school use societies to address drug and } \\
\text { substance abuse? }\end{array}$ & $\begin{array}{l}\text { Yes } \\
\text { No } \\
\text { total }\end{array}$ & $\begin{array}{l}300 \\
101 \\
401\end{array}$ & $\begin{array}{c}74.8 \\
25.2 \\
100.0\end{array}$ \\
\hline $\begin{array}{c}\text { Does your school use skits to address drug and } \\
\text { substance abuse? }\end{array}$ & $\begin{array}{l}\text { Yes } \\
\text { No } \\
\text { total }\end{array}$ & $\begin{array}{l}118 \\
283 \\
401\end{array}$ & $\begin{array}{c}29.4 \\
70.6 \\
100.0\end{array}$ \\
\hline $\begin{array}{l}\text { Does your school use play to address drug and substance } \\
\text { abuse? }\end{array}$ & $\begin{array}{c}\text { Yes } \\
\text { No } \\
\text { total }\end{array}$ & $\begin{array}{l}209 \\
192 \\
401\end{array}$ & $\begin{array}{c}52.1 \\
47.9 \\
100.0\end{array}$ \\
\hline $\begin{array}{c}\text { Does your school use music to address drug and } \\
\text { substance abuse? }\end{array}$ & $\begin{array}{l}\text { Yes } \\
\text { No } \\
\text { total }\end{array}$ & $\begin{array}{c}64 \\
337 \\
401 \\
\end{array}$ & $\begin{array}{c}16.0 \\
84.0 \\
100.0\end{array}$ \\
\hline $\begin{array}{c}\text { Does your school use drama to address drug and } \\
\text { substance abuse? }\end{array}$ & $\begin{array}{c}\text { Yes } \\
\text { No } \\
\text { total }\end{array}$ & $\begin{array}{l}203 \\
198 \\
401\end{array}$ & $\begin{array}{l}50.6 \\
49.4 \\
100\end{array}$ \\
\hline
\end{tabular}

\section{Table 2: Use of Peers}

Table shows the most commonly used form of peer education activities to address drug and substance abuse were societies at 47.8 percent followed by plays at 52.1 percent. The findings could be informed by the fact that societies are programmed on a weekly basis and they could be used to discourage drug and substance abuse in schools. Use of plays is a rather innovative approach since it is likely to capture the attention of young students in schools. The next subsection focuses on the frequency of abuse of various forms of drugs in schools.

\begin{tabular}{|c|c|c|c|c|c|c|}
\hline Statement & $\begin{array}{c}\text { Very Commonly } \\
\text { Abused }\end{array}$ & $\begin{array}{c}\text { Commonly } \\
\text { Abused }\end{array}$ & $\begin{array}{c}\text { Fairly } \\
\text { Abused }\end{array}$ & $\begin{array}{c}\text { Rarely } \\
\text { Abused }\end{array}$ & $\begin{array}{c}\text { Never } \\
\text { Abused }\end{array}$ & Total \\
\hline $\begin{array}{c}\text { Frequency Of } \\
\text { Alcohol Abuse By } \\
\text { Students }\end{array}$ & $\begin{array}{c}172 \\
(42.9 \%)\end{array}$ & $\begin{array}{c}179 \\
(44.6 \%)\end{array}$ & $\begin{array}{c}6 \\
(1.5 \%)\end{array}$ & $\begin{array}{c}21 \\
(5.2 \%)\end{array}$ & $\begin{array}{c}23 \\
(5.7 \%)\end{array}$ & $\begin{array}{c}401 \\
100 \%\end{array}$ \\
\hline $\begin{array}{c}\text { Frequency Of } \\
\text { Tobacco Abuse By } \\
\text { Students }\end{array}$ & $\begin{array}{c}151 \\
37.7 \%\end{array}$ & $\begin{array}{c}149 \\
37.2 \%\end{array}$ & $\begin{array}{c}69 \\
17.2 \%\end{array}$ & $\begin{array}{c}15 \\
3.7 \%\end{array}$ & $\begin{array}{c}17 \\
4.2 \%\end{array}$ & $\begin{array}{c}401 \\
100 \%\end{array}$ \\
\hline $\begin{array}{c}\text { Frequency Of } \\
\text { Cigarettes Abuse } \\
\text { By Students }\end{array}$ & $\begin{array}{c}72 \\
18.0 \%\end{array}$ & $\begin{array}{c}197 \\
49.1 \%\end{array}$ & $\begin{array}{c}36 \\
9.0 \%\end{array}$ & $\begin{array}{c}66 \\
16.5 \%\end{array}$ & $\begin{array}{c}29 \\
7.2 \%\end{array}$ & $\begin{array}{c}401 \\
99.8 \\
\text { Missing } \\
\text { System } \\
1 \\
(2 \%) \\
\text { Final } \\
\text { Total } 401\end{array}$ \\
\hline $\begin{array}{l}\text { Frequency Of } \\
\text { Miraa Abuse By } \\
\text { Students }\end{array}$ & $\begin{array}{c}167 \\
41.6 \%\end{array}$ & $\begin{array}{c}172 \\
42.9 \%\end{array}$ & $\begin{array}{c}19 \\
4.7 \%\end{array}$ & $\begin{array}{c}26 \\
6.5 \%\end{array}$ & $\begin{array}{c}17 \\
4.2 \%\end{array}$ & $\begin{array}{c}401 \\
100 \%\end{array}$ \\
\hline $\begin{array}{c}\text { Frequency Of } \\
\text { Cocaine Abuse By } \\
\text { Students }\end{array}$ & $\begin{array}{l}110 \\
27.4\end{array}$ & $\begin{array}{c}24 \\
6.0 \%\end{array}$ & $\begin{array}{c}114 \\
28.4 \%\end{array}$ & $\begin{array}{c}22 \\
5.5 \%\end{array}$ & $\begin{array}{c}131 \\
32.7 \%\end{array}$ & $\begin{array}{c}401 \\
100 \%\end{array}$ \\
\hline $\begin{array}{c}\text { Frequency Of } \\
\text { Bhang Abuse By } \\
\text { Students }\end{array}$ & $\begin{array}{c}231 \\
57.6 \%\end{array}$ & $\begin{array}{c}122 \\
30.4 \%\end{array}$ & $\begin{array}{c}4 \\
1.0 \%\end{array}$ & $\begin{array}{c}9 \\
2.2 \%\end{array}$ & $\begin{array}{c}33 \\
6.2 \%\end{array}$ & $\begin{array}{c}399 \\
99.5 \% \\
\text { Missing } \\
\text { System } 2 \\
(5 \%) \\
\text { Total } 401\end{array}$ \\
\hline $\begin{array}{c}\text { Frequency Of } \\
\text { Rubber Abuse By } \\
\text { Students } \\
\end{array}$ & $\begin{array}{c}163 \\
40.6 \%\end{array}$ & $\begin{array}{c}64 \\
16.0 \%\end{array}$ & $\begin{array}{c}39 \\
9.7 \%\end{array}$ & $\begin{array}{c}79 \\
19.7 \%\end{array}$ & $\begin{array}{c}56 \\
14.0 \%\end{array}$ & $\begin{array}{c}401 \\
100 \%\end{array}$ \\
\hline $\begin{array}{c}\text { Frequency Of } \\
\text { Heroine Abuse By } \\
\text { Students }\end{array}$ & $\begin{array}{c}84 \\
20.9 \%\end{array}$ & $\begin{array}{c}68 \\
17.0 \%\end{array}$ & $\begin{array}{c}63 \\
15.7 \%\end{array}$ & $\begin{array}{c}51 \\
12.7 \%\end{array}$ & $\begin{array}{c}135 \\
33.7 \%\end{array}$ & $\begin{array}{c}401 \\
100 \%\end{array}$ \\
\hline $\begin{array}{c}\text { Frequency Of } \\
\text { Mandrax } \\
\text { Abuse By Students }\end{array}$ & $\begin{array}{c}77 \\
19.1 \%\end{array}$ & $\begin{array}{c}20 \\
(50 \%)\end{array}$ & $\begin{array}{c}99 \\
24.7 \%\end{array}$ & $\begin{array}{c}76 \\
19.0 \%\end{array}$ & $\begin{array}{c}129 \\
32.2 \%\end{array}$ & $\begin{array}{c}401 \\
100 \%\end{array}$ \\
\hline $\begin{array}{c}\text { Frequency Of } \\
\text { Hashish Abuse By } \\
\text { Students } \\
\end{array}$ & $\begin{array}{c}38 \\
9.4 \%\end{array}$ & $\begin{array}{c}71 \\
17.7 \%\end{array}$ & $\begin{array}{c}44 \\
11.0 \%\end{array}$ & $\begin{array}{c}192 \\
47.9 \%\end{array}$ & $\begin{array}{c}56 \\
14.0 \%\end{array}$ & $\begin{array}{c}401 \\
100 \%\end{array}$ \\
\hline
\end{tabular}

Table 3: Frequency of Abuse of Various Forms of Drugs in Schools 
The table shows the most commonly abused drug and substance is alcohol with 42.9 percent with a frequency of 172.It is followed by miraa with a frequency of 167 at $41.6 \%$. This cuts across in all the public secondary schools in Busia county.

\begin{tabular}{|c|c|c|}
\hline $\begin{array}{c}\text { Does your school use peer no address } \\
\text { substance abuse }\end{array}$ & Yes & 261 \\
\hline $\begin{array}{c}\text { do you have school mates who abuse } \\
\text { drugs }\end{array}$ & No & 140 \\
\hline
\end{tabular}

Table 4: Use of Peer Education and Drug and Substance Abuse

The table 4 shows that out of 401, 261 were secondary schoolmates who abuse drug and substance at 65.1 percent, while 140 do not have schoolmates who abuse drug and substance at 34.9 percent. Table 4 shows that 261 respondents have students who abuse drug and substance and therefore this implies that peer education is needed in schools as principal's administrative practice to cub down the problem.

\begin{tabular}{|c|c|c|}
\hline & & Mean \\
\hline Does your school use peer to address substance abuse & Yes & 1.0038 \\
Do you have school mates who abuse drugs & No & 1.0857 \\
\hline
\end{tabular}

Table 5: Group Statistics of Peer Education

The table shows group statistics shows that the mean for school mates who abuse drugs is 1.0038 while for those who do not abuse drugs is 1.0857

\begin{tabular}{|cc|c|}
\hline & std. Deviation \\
\hline Does your school use peer to address substance abuse & Yes & 0.6190 \\
\hline Do you have & No & .28095 \\
\hline
\end{tabular}

Table 6: Standard Deviation of Peer Education

Table shows standard deviation for the abusers of drug and substance is 0.6190 .While those who do not abuse drug is 0.02374

Table shows the standard error deviation with those who acknowledged the use of peer education having 0 . 0383.While those who didn't acknowledge the use of peer education having 0.02374 .

\begin{tabular}{|c|c|c|c|c|}
\hline \multicolumn{2}{|c|}{} & $\begin{array}{c}\text { Levene's Test For Equality } \\
\text { of Variances }\end{array}$ & $\begin{array}{c}\text { T. Test for Equality } \\
\text { of Means }\end{array}$ \\
\cline { 3 - 5 } & F & Sig & $t$ \\
\hline $\begin{array}{c}\text { Do you have } \\
\text { schoolmates who } \\
\text { abuse drugs }\end{array}$ & $\begin{array}{c}\text { Equal variances } \\
\text { assumed }\end{array}$ & 94.944 & .000 & -4.513 \\
\cline { 2 - 5 } & $\begin{array}{c}\text { equal variances not } \\
\text { assumed }\end{array}$ & & & -3.404 \\
\hline
\end{tabular}

Table 7: Independent Samples Test

Table shows Independent samples test shows that the t-test for equality of variances assumed is 94.944 , significance 0.000 and equality of means is -4 . 513.The $t$-test shows it is -4.513 for the equal variances assumed and the ttest for equal variances not assumed is -3.404. This means that there is significant difference on using peer education. The t-test shows the variances are not assumed and all were taken into consideration.

\begin{tabular}{|c|c|c|c|c|}
\hline & \multicolumn{4}{|c|}{ t. test for equality of means } \\
\cline { 2 - 5 } & & Df & sig. (2 tailed) & Mean difference \\
\hline $\begin{array}{c}\text { Do you have } \\
\text { schoolmates } \\
\text { who abuse } \\
\text { drugs }\end{array}$ & $\begin{array}{c}\text { Equal variances } \\
\text { assumed }\end{array}$ & 399 & .000 & -0.8188 \\
\cline { 2 - 5 } & $\begin{array}{c}\text { Equal variances not } \\
\text { assumed }\end{array}$ & 146280 & .001 & -08188 \\
\hline
\end{tabular}

Table 8: Independent Sample Test Sig (2-Tailed) And Mean Difference

Table shows t-test for independent sample sig. ( 2 tailed) shows that when using the mean difference, the result was 0.01888 for equal variances assumed. While the $t$ test for equal variances not assumed is -0.8188 and this acts as a mean difference. This implies that there is a significance difference of the mean differences. The sig. ( 2 tailed) $t$ test means test for two or more than two items in the study. 


\begin{tabular}{|c|c|c|}
\hline & $\begin{array}{c}\text { T. Test for Equality of Means } \\
\text { Std. Error Difference }\end{array}$ \\
\hline $\begin{array}{l}\text { Do you have schoolmates who } \\
\text { abuse drugs. }\end{array}$ & Equal variances assumed & 0.1814 \\
\hline & Equal variance not assumed & 0.2405 \\
\hline
\end{tabular}

Table 9: Independent Samples Test for Standard Error Difference

The table shows Independent sample test on the standard error difference shows it is 0.184 on the variances assumed while on the equal variance not assumed is 0 .2405.This implies that there is a significant difference on peer education as a method used on prevalence of drug and substance.

\begin{tabular}{|c|c|c|}
\hline \multirow{2}{*}{} & \multicolumn{2}{|c|}{ t. test for equality of means } \\
\cline { 2 - 3 } & \multicolumn{2}{|c|}{$95 \%$ confidence interval of the difference } \\
\cline { 2 - 3 } & Lower & Upper \\
\hline $\begin{array}{c}\text { Do you have school mates who } \\
\text { abuse drugs }\end{array}$ & -11755 & -04622 \\
\hline
\end{tabular}

Table 10: Independent Samples Test for T.Test Equality of Means

The table shows independent test for equality of means 95\% confidence interval of the intervals was with two levels, that is, the lower having -11755 and the upper was -04622 . This shows that there is significant difference in using peer education on prevalence of drug and substance abuse. The $t$ test on peer education on prevalence of drug and substance abuse has significant difference on the levels of drug and substance in those schools where it exists because the figure show it is less than 0.5 . Any figure less than 0.5 shows it is significant.

There is a significant difference which exists between levels on prevalence of drug and substance abuse in schools where principals supported peer education versus those which do not support peer education. Those schools which have peer education have higher levels or prevalence of drug and substance abuse compared to those schools which do not practice the exercise. Peer education was carried out in 29 schools and only 6 schools do not have it.

According to the previous study of Carnigie, Turner (2009) and Shinner (1999) which states that peer education success lies among individuals who identify with a particular culture, it is therefore concurring with this study where principals are passing on information to the students through peer education to prevail the culture of drug and substance abuse among students in public secondary schools. For example, a principal from one of the extra county schools had to say that peer education is one of the administrative practices assisting the curbing down of drug and substance abuse in a public secondary school. All schools should practice it so as to improve in academic performance. He also stated that schools which perform well, have a reduction in drug and substance abuse. The focus group discussion of education officers concurred with the use of peer education in public secondary schools at 100 percent. The researcher found out that there is significant difference in schools which carry out peer education compared to those which do not because the figure is less than 0.5 .

\subsection{Drugs abused in Schools}

The drugs abused in schools are: alcohol, tobacco, cigarettes, miraa, cocaine, bhang, heroine, kubber, mandrax and hashish. The highest drug and substance with a frequency being abused is bhang with 231 respondents and a percentage of 57.6 while the lowest drug and substance abuse is hashish and has a frequency of 38 with a percentage of 9.4. There are ten types of drug and substance abused in public secondary schools in Busia County, Kenya.

\subsection{Source of Drug and Substance}

There are three sources where the students get drug and substance. The drug and substance are sneaked in by students, the students obtain the drugs from outside peddlers and finally they are sneaked in by non-teaching staff. The most common sources are sneaking in by students and nonteaching staff.

Measures that were be taken to control drug and substance abuse in public secondary schools in Busia county in Kenya are: By verbal warning on the students on drug and substance abuse, by expelling students who abuse drug and substances, by inviting parents to talk with their children on prevalence of drug and substance abuse and lastly by arraigning in court the students who are got abusing drug and substance.

\section{Conclusion}

The study concluded that peer education positively influenced students' behavior in the sense that they reduced drug and substance abuse among students.

\section{Recommendations}

- The study recommends embracing peer education in all secondary schools where they were not yet embraced as a preemptive measure.

- The study should be carried out in private secondary schools and primary schools in other parts of the republic where the drug and substance are a menace. 
- The study also recommended that the ways in which peers participated to address the prevalence on drug and substance abuse in public secondary schools in Busia County, Kenya should be enhanced.

\section{Suggestions for Further Study}

- The study should be carried out also in urban centers of schools where it is not embraced.

- The study should be carried out in private secondary schools and primary schools in other parts of the republic where the drug and substance are a menace

- All drug and substance should be abolished in all public secondary schools in Busia County, Kenya.

\section{References}

i. Affinity, (2008). Transit points in any international drug network to consumer countries Balding, J. (2011). Trends: young people and illegal drugs. Attitudes to and experience of illegal drugs 1987-2004. Exeter: schools health education unit.

ii. Best and Kahn (2010). Sample as a small proportion selected for observation and analysis.

iii. Bleeker, (2012). Peer Education as a Process of Sharing Information.

iv. Borg, R.W. \& Gall, (1996). Educational research. (6 $6^{\text {th }}$ ed.) New York: Longman Inc.

v. Botvin, G. J. (2010). "Preventing drug abuse in schools: social and Competence enhancement approaches targeting individual-level etiological factors." addictive behaviours 25, 887 - 897.

vi. Carnigie, D. Turner \& Shinner, (1999). Drug Abuse in the Republic of Ireland: An Overview, Bulletin on Narcotics. 38 (1-2): 91-97.

vii. Chand, S. (2008). Guidance and counselling (For teachers, parents and students). New Delhi: S. Chand and company Ltd.

viii. Chandler, R. K., Fletcher, B. W., \& Volkow, N. D. (2009). Treating drug abuse and addiction in the criminal justice system: improving public health and safety. Jama, 301(2), 183-190.

ix. Darcis, J. (2004). Youth in Peril. Alcohol and drug abuse in Kenya. Nairobi: Baseline survey.

x. Etinberger, K. W., Runyon, R. P \& Haber, A. (1990). Fundamentals of social statistics. (2nd ed.) New York: McGrawHill, Inc.

xi. Hyman \& Perone, (1998). Learning opportunities presented by those who are in similar situations to themselves.

xii. Imbosa, M. (2009). An Investigation into Strategies Used in Addressing Drug

xiii. Abuse Problems: A Case Study of Nairobi Provincial Boys' Secondary Schools. A Master of Education Research Project Report, Kenyatta University.

xiv. Khanyisile, T. (2010). Evaluation of Primary Prevention of Substance Abuse Programme amongst Young People at Tembiso. Master of Arts Dissertation: Faculty of Arts. University of Johannesburg: South Africa.

xv. Lewis N.M \& Thornwill (2007). Formulae provided for presentation of the sample size per class and gender.

xvi. Maithya, R. W. (2009). Drug abuse in secondary schools in Kenya: Developing a programme for prevention and intervention. Doctor of Education in socio-Education, University of South Africa.

xvii. Matsigulu, M. M. (2006). The role of the Kenya music festival in eradicating Drug and Substance Abuse in public secondary schools in Kikuyudivision Kiambu District, Kenya. Unpublished Master of Education Project. University of Nairobi.

xviii. Mugenda, A. G. (2008). Social Science Research: Theory and principles. Nairobi: Applied Research and Training Services.

xix. Mugenda,O. M. \& Mugenda A.G. (2003). Sampling Frame as a List, directing or index of cases selected.

xx. Mungai, J. G. (2007). The role of head teachers in promoting drug abuse counselling among students in public secondary schools in Nyeri and Mbeere Districts. A PhD Thesis, Kenyatta University.

xxi. Muraguri, C.W. (2004). The role of drama in Eradicating Drug and

xxii. Substance Abuse in secondary schools in Starehe and Kamukunji divisions. Unpublished M.Ed. project.

xxiii. NACADA(2006); and Republic of Kenya(2008). Ease of availability and slum life which make many students vulnerable to the allure of drugs

xxiv. Ng'ang'a, R. M. (2007) and Poipoi (1998). A study of participatory approaches used by the Head teachers to control drug abuse in public secondary schools in Nyeri District. Unpublished M.Ed Thesis. University of Nairobi

xxv. Ngesu, L. M., Ndiku, J. \& Masese, A. (2008). Drug dependence and abuse in Kenyan secondary schools: strategies for intervention. Educational research and reviewvol.3 (10), pp304-308.http:/ / www.academic journals.org/ EPR.

xxvi. United Nations Office on Drugs and Crime, 2013 reduction on the global illicit drug supply and demand

xxvii. Obiero, J. A. (2006). The Effect of the administrative practice on Kenya

xxviii. Certificate of Primary Education performance in Maseno Division Kisumu District. Unpublished M.Ed research project, University of Nairobi.

xxix. Orodho, J.A. \& Kombo, D.K. (2003). Descriptive Survey Methods on Education and Social Issues.

xxx. Okumbe, J. A. (2001). Human Resource Management. An Educational Perspective. Nairobi: Educational development and research bureau.

xxxi. Olatuwara \& Odejide, (2006) Major hindrances to fight against drug related crime in many African countries

xxxii. Republic of Kenya, (2005). Teachers' code of ethics and conduct prohibits smoking And drinking in the presence of students Republic of Kenya, ( 2008). Established peer education in schools 